\title{
PENGARUH PERSAINGAN DAN KEKUATAN PEMBELI TERHADAP HUBUNGAN PEMASOK-RITEL MODERN DI JAKARTA
}

\author{
Dedie S. Martadisastra, Arief Daryanto, Bustanul Arifin, Endang Gumbira-Sa'id \\ Program Doktor Manajemen dan Bisnis IPB, Direktur Pascasarjana MB-IPB Bogor; \\ Guru Besar MB-IPB Bogor \\ Email:dediesmart@yahoo.com
}

\begin{abstract}
The aim of the study was to investigate the development of domestic supplier performances as the result of modern retail-supplier business relationships which they had controlled by the effect of combinations on competition and buyer power. The paper presents the results of a survey of packaged processed foods suppliers, which formed part of a wider study of buyer-supplier relationships in Indonesia's modern retail supply chains. The findings of this study indicate that the results demonstrate the heterogeneity relationships between supplier and modern retail in the main commodity grocery sectors. The extent to which modern retail challenged by competition, supply chain strategy and market share are likely to influence the way in which modern retail deal with suppliers. A part of the suppliers indicated that they get benefited substantially from the presence of modern retail, however, they also face several challenges brought about by buyer power as imposition of several unfair relationship terms, price fixing, and poorly supervision as cause of the development and growth of suppliers limitedly. This study attempts to show the results of the research in Indonesia to empirically measure the effect of competition and buyer power on modern retail-supplier relationships. The further research is needed to refine the results of this initial study.
\end{abstract}

Keywords: Competition, Buyer Power, Modern Retail-Supplier Relationships.

Abstrak: Tujuan dari penelitian ini adalah untuk menyelidiki pengembangan kinerja pemasok domestik sebagai hasil dari hubungan bisnis ritel-supplier yang modern yang mereka telah dikendalikan oleh pengaruh kombinasi pada kompetisi dan kekuatan pembeli. Makalah ini menyajikan hasil survei terhadap kemasan makanan olahan pemasok, yang merupakan bagian dari studi yang lebih luas dari hubungan pembelipemasok dalam rantai pasokan ritel di Indonesia modern. Temuan penelitian ini menunjukkan bahwa hasil menunjukkan hubungan antara pemasok dan heterogenitas ritel modern di sektor komoditas bahan makanan utama. Sejauh mana ritel modern ditantang oleh kompetisi, strategi rantai pasokan dan pangsa pasar cenderung mempengaruhi cara di mana kesepakatan ritel modern dengan pemasok. Sebuah bagian dari pemasok mengindikasikan bahwa mereka mendapatkan manfaat substansial dari kehadiran ritel modern, bagaimanapun, mereka juga menghadapi beberapa tantangan yang ditimbulkan oleh kekuatan pembeli sebagai pengenaan beberapa istilah hubungan yang tidak adil, penetapan harga, dan pengawasan buruk sebagai penyebab pengembangan dan pertumbuhan pemasok secara terbatas. Penelitian ini mencoba untuk menunjukkan hasil penelitian di Indonesia untuk mengukur secara empiris pengaruh persaingan dan kekuasaan pembeli pada hubungan ritel-supplier modern. Penelitian lebih lanjut diperlukan untuk memperbaiki hasil penelitian awal ini.

Kata kunci: Kompetisi, Pembeli Power, Hubungan Retail-Pemasok. 


\section{PENDAHULUAN}

Dalam mengantisipasi praktek perdagangan tidak sehat, pola pikir otoritas persaingan di negara maju dan negara berkembang, semakin mengalami perkembangan dari mulai pola pikir konvensional, evolusi sampai dengan modern (Berasategi 2013). Pola pikir konvensional mengemukakan tinjauan mengenai kekuatan penjual yang meliputi Interbrand competition dan intra-brand competition. Inter-brand competition adalah persaingan antar pemasok dan atau ritel modern dalam memasarkan produknya atas dasar merek atau label dengan strategi diferensiasi, sedangkan intra-brand competition adalah persaingan diantara ritel modern dalam menjual produk dari merek yang sama dan menyangkut syarat harga atau non-harga (OECD 2013). Dalam tinjauan konvensional tersebut, ritel modern dengan kekuatan pembeli dapat memperoleh harga pembelian produk lebih rendah dan juga dapat menentukan harga jual produk lebih rendah (Chen 2008). Dalam evolusinya, ritel modern meningkatkan pangsa pasar dan konsentrasi, sehingga meningkatkan kekuatan pembeli yang menyebabkan ketidak-seimbangan kekuatan posisi tawar dalam rantai pasokan, pengurangan persaingan pemasok, mempengaruhi konsumen melalui pengurangan inovasi, kerugian jangka panjang, pengurangan pilihan dan harga lebih tinggi. Pengaruh tersebut sering diabaikan, sehingga mempengaruhi terhadap kesinambungan konsumsi dan produksi (Nicholson dan Young 2012). Pola pikir persaingan modern, menyatakan platform ritel modern adalah tempat yang memiliki kendala dan potensi terjadinya persaingan tidak sehat (competitive bottlenecks) dan memiliki dua-sisi pasar (two-sided markets) (Rochet dan Tirole 2002, 2005; Amstrong dan Wright 2012). Ritel modern dalam mengurangi peningkatan kekuatan posisi tawar pemasoknya, melakukan peningkatan kekuatan pasarnya terlebih dahulu, dengan penguasaan pangsa pasar di pasar konsumen (downstream market). Penguasaan pasar dan posisi dominan dapat digunakan sebagai sarana negosiasi persyaratan pada pasar pemasok (upstream market), dengan menerapkan syarat-syarat yang memberi keuntungan lebih, termasuk pemotongan harga. Contoh dua-sisi pasar di atas adalah pada pasar kartu kredit, dimana bank akan memiliki dua sisi pasar yang dihadapi, yaitu pasar nasabah pemegang kartu kredit dan pasar merchant (Berasategi 2010, 2013).

Dalam persaingan ritel modern, kepentingan pemasok dan konsumen berkaitan erat. Kerugian pada satu kelompok cenderung merugikan ke kelompok lainnya, pemasok dan konsumen berada dalam perahu yang sama. Ketertarikan konsumen terhadap perilaku persaingan ritel modern dapat dinilai melalui konsep pelayanan, harga, kualitas dan range (Nicholson dan Young 2012). Pelayanan meliputi semua pengalaman yang dirasakan oleh konsumen dalam melakukan belanja di ritel modern, antara lain pengaturan antrian, kebersihan, ketertiban, karyawan yang siap membantu, kenyamanan parkir dan lokasi geografis. Harga dan kualitas secara langsung dikendalikan oleh ritel modern melalui persyaratan. Range berkaitan dengan pengendalian ritel modern terhadap pemasok dan konsumen serta bertindak sebagai "penjaga gawang" rantai pasokan. Ritel modern tidak memproduksikan produk apapun, namun menciptakan situasi, dimana pemasok memperoleh tempat penyimpanan produk pada kondisi yang ditentukan oleh ritel modern, sedangkan konsumen memiliki kelemahan untuk menjangkau produsen, sehingga konsumen membeli produk berdasarkan apa yang dipilih oleh ritel modern (Nicholson dan Young 2012).

Persaingan ritel modern dan pemasoknya di Indonesia sangat ketat seiring dengan peningkatan jumlah gerai ritel modern maupun pemasoknya sangat cepat, yang disebabkan liberalisasi regulasi industri ritel. Persaingan sangat ketat tersebut membentuk 
konsentrasi, kekuatan posisi tawar, kekuatan pembeli ritel modern meningkat, sehingga mengakibatkan timbulnya perilaku anti-persaingan dan hubungan pemasok-ritel modern menjadi tidak seimbang serta merugikan pemasok (Muslimin dan Nuryati 2007, Muslim dan Febriana 2008, Pandin 2009). Walaupun pemerintah telah mengantisipasi penyimpangan tersebut dengan menerbitkan beberapa regulasi dan kebijakan persaingan, yaitu Perpres 112/2007, Permendag 53/2008, UU 5/1999, UU 8/1999. Namun pelanggaran persaingan tersebut masih terjadi. Pada tahun 2005, ritel modern Carrefour memberlakukan hubungan usaha yang memberatkan pemasoknya dan kedua pada tahun 2009, ritel modern Carrefour meningkatkan konsentrasi pasar dan mengeksploitasi surplus pemasoknya, sehingga mengakibatkan ketidak-seimbangan dan dampak negatif terhadap persaingan. Kebijakan persaingan dapat digunakan untuk mengatasi pelanggaran akibat konsentrasi pasar dan kekuatan pembeli (Dodd dan Asfaha 2008). Penting sekali untuk menjamin persaingan sehat, dimana konsentrasi pasar ritel modern tidak mengakibatkan penyalahgunaan kekuatan pasar dalam membentuk penguasaan pasar (Chowdhury et al. 2005). Otoritas persaingan Indonesia berdasarkan kebijakan persaingan UU/5/1999 telah menghukum dan memberikan sanksi denda terhadap ritel modern Carrefour terhadap kedua pelanggaran persaingan tersebut (KPPU 2009).

Kondisi ketidak-seimbangan hubungan pemasok-ritel modern dalam persaingan tersebut melibatkan berbagai faktor kompleks. Namun sangat menarik untuk dilakukan penelitian, diantaranya sampai sejauh mana persaingan, kekuatan posisi tawar dan kekuatan pembeli tersebut pada saat ini mempengaruhi kemitraan atau hubungan usaha pemasok-ritel modern. Oleh karena itu tujuan penelitian ini dapat ditentukan, sebagai berikut: (1) Mengetahui pengaruh persaingan terhadap hubungan pemasok-ritel modern; (2) Mengetahui pengaruh kekuatan pembeli terhadap hubungan pemasok-ritel modern.

Kajian Teoritis. Penelitian ini menggunakan grand theory yang paling mendekati model pengaruh persaingan dan kekuatan pembeli (buyer power) terhadap hubungan pemasokritel modern, yaitu teori organisasi industri, khususnya paradigma struktur pasar, perilaku, kinerja dan model persaingan kekuatan lima porter (Porter's five forces) serta dilengkapi dengan konsep kekuatan pembeli dan konsep hubungan pemasaran (relationship marketing), khususnya konsep hubungan pembeli-penjual.

Persaingan. Porter (1980, 1985) dalam Hunt (2001) mengemukakan bahwa persaingan adalah usaha yang terus menerus dilakukan antar perusahaan untuk meraih keunggulan komparatif dalam sumberdaya yang akan menghasilkan posisi keunggulan bersaing di pasar dan paling penting adalah meraih kinerja keuangan super. Udayasankar et al. (2009) menambahkan bahwa persaingan adalah mekanisme operasi pasar yang membolehkan perilaku usaha beroperasi secara wajar dan memiliki kecenderungan, bila persaingan lebih ketat menyebabkan pasar menjadi lebih efisien. Persaingan merupakan pertandingan antar perusahaan dalam menjual barang dan jasa, yang perusahaan hasilkan kepada konsumen (KPPU 2009). Perusahaan melakukan antisipasi terhadap perubahan regulasi yang mempengaruhi struktur pasar persaingan (Akpinar 2007).

Struktur pasar persaingan dapat dibagi menjadi empat kategori, yaitu pasar persaingan sempurna, pasar monopoli, pasar persaingan monopolistis, pasar oligopoli. Karakteristik pasar persaingan sempurna, jumlah perusahaan banyak dan kemampuan setiap perusahaan sangat kecil untuk mempengaruhi harga pasar. Pasar monopoli, hanya ada satu produsen atau penjual barang atau jasa dalam pasar bersangkutan. Barang dan jasa yang dihasilkan tidak mempunyai substitusi. Pasar persaingan monopolistis, banyak 
perusahaan dan konsumen, seperti persaingan sempurna. Namun setiap perusahaan memproduksikan produk yang berbeda dari produk perusahaan lainnya. Pasar oligopoli, beberapa perusahaan cenderung mendominasi pasar dan cenderung terkonsentrasi. Ketika suatu perusahaan dalam pasar oligopoli berubah perilakunya, perusahaan lain melakukan reaksi. Pengukuran konsentrasi perusahaan di pasar, yaitu rasio konsentrasi, ukuran pasar secara keseluruhan dan ukuran pasar perusahaan yang memimpin pasar. Indeks Hirschman-Herfindahl merupakan penjumlahan kuadrat pangsa pasar semua perusahaan dalam suatu industri (Baye 2009).

Model kerangka lima kekuatan porter menyatakan bahwa struktur suatu industri menentukan perilaku persaingan antar perusahaan, kekuatan posisi tawar pemasok, kekuatan posisi tawar pembeli, ancaman pendatang baru, ancaman substitusi dan persaingan diantara pesaing, membuat industri tersebut menjadi menarik dan berpotensi meraih laba untuk bersaing didalamnya. Dengan demikian, persaingan dalam sebuah industri tergantung atas lima kekuatan dasar persaingan tersebut (Porter 2004 ; Ehmke et al. 2009). Pada Gambar 1 di bawah ini diperlihatkan kekuatan lima porter.

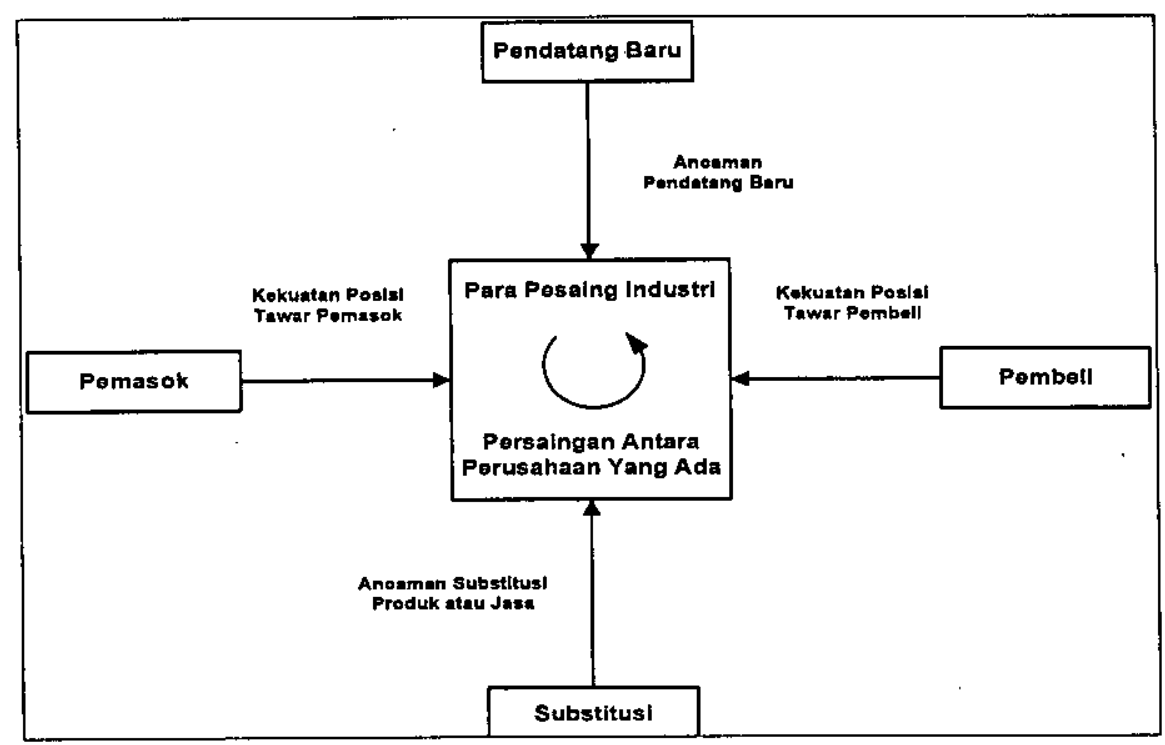

Gambar 1. Model Kekuatan Yang Mendorong Persaingan Industri Sumber: Porter 2004

Dalam persaingan, pemasok dapat memiliki kekuatan posisi tawar lemah atau kuat, yang mempengaruhi syarat dan kondisi transaksi yang dilakukan. Transaksi pemasok dan pembeli menciptakan nilai bagi kedua pihak. Namun apabila pembeli memiliki kekuatan posisi tawar lebih besar, kemampuan pemasok untuk meraih nilai proporsi tinggi menurun dan laba lebih rendah. Kekuatan posisi tawar pembeli mempengaruhi besar laba yang diperoleh pemasok. Kekuatan posisi tawar pembeli adalah salah satu dari lima kekuatan yang menentukan intensitas persaingan dalam industri. Pembeli dapat mengurangi kekuatan posisi tawar pemasok dengan meningkatkan loyalitas pada pembeli melalui kemitraan atau program loyalitas, penjualan secara langsung ke konsumen, atau peningkatan keakraban atau nilai penerimaan produk dengan menambah fitur atau merek. (Porter 2004, Ehmke et al. 2009). 
Analisis ancaman pendatang baru meliputi pengujian hambatan masuk (barrier to entry) dan reaksi perusahaan terhadap pesaing baru. Sumber hambatan pemain baru untuk masuk dalam persaingan di pasar, yaitu: (1) Skala ekonomi; (2) Differensiasi produk; (3) Persyaratan kapital; (4) Biaya peralihan (5) Akses ke saluran distribusi; (6) Skala biaya kerugian independen; (7) Kebijakan pemerintah (Porter, 1990, 2004). Untuk mengurangi ancaman dari pendatang baru, yaitu: Meningkatkan citra merek, mendayagunakan paten dan melakukan persekutuan dengan asosiasi produk. Persaingan perusahaan di pasar mengambil bentuk berupa perebutan posisi dengan menggunakan berbagai taktik, antara lain: Persaingan harga, perang iklan, perkenalan produk (Porter 2004, Ehmke et al. 2009).

Perusahaan di pasar memiliki kesaling-tergantungan, biasanya mengundang reaksi pesaingnya, apabila ada aksi. Persaingan antara perusahaan meningkatkan intensitasnya, ketika salah satu perusahaan mengalami tekanan persaingan, maka tekanan persaingan tersebut dijadikan peluang oleh perusahaan untuk memperbaiki posisinya. Intensitas persaingan adalah tingkat persaingan pasar (Dunn dan Young 2004 dalam Chuah et al. 2010). Ketika pemasok produk yang sama berjumlah banyak, maka tingkat persaingan pemasok ketat, sehingga intensitas persaingan tinggi. Persaingan juga dapat ditinjau sebagai fungsi halangan masuk ke pasar dan tingkat diferensiasi. Karakteristik intensitas persaingan tinggi adalah siklus hidup produk pendek, permintaan konsumen kritis terhadap biaya dan kualitas serta cepatnya peluncuran produk baru (Atuahene-Gima dan Ko 2001 dalam Chuah et al. 2010).

Kekuatan Pembeli. Secara spesifik, beberapa peneliti mendefinisikan kekuatan pembeli sebagai kekuatan posisi tawar (bargaining power) atau kekuatan pengimbang (countervailing power). Namun beberapa peneliti lain mengartikan kekuatan pembeli sebagai kekuatan permintaan harga lebih rendah, yang meliputi pengertian, yaitu: (1) Kekuatan pembeli lebih luas daripada kekuatan monopsoni; (2) Kekuatan pembeli lebih daripada kemampuan untuk mengurangi harga (Chen 2008). Dodd dan Asfaha (2008) mengemukakan beberapa definisi kekuatan pembeli dari tiga peneliti, yaitu: (1) Kekuatan pembeli ada ketika perusahaan memiliki posisi dominan sebagai pembeli barang atau jasa atau karena memiliki keunggulan strategis dan pengungkit timbuinya pendapatan (leverage) sebagai akibat skala usahanya atau karakteristik lain, sehingga memperoleh syarat-syarat transaksi perdagangan yang lebih menguntungkan dari pemasok daripada pembeli lainnya (OECD 1981); (2) Kekuatan pembeli terjadi, ketika sebuah perusahaan atau kelompok perusahaan memperoleh syarat-syarat transaksi perdagangan lebih menguntungkan dari pemasok daripada pembeli lainnya atau mendapat harga dan nonharga dibawah kondisi persaingan normal (Dobson et al. 2008); (3) Kekuatan pembeli adalah kekuatan posisi tawar pembeli terhadap pemasok dalam negosiasi usaha. Oleh karena skala usaha dan signifikansi usaha pembeli, maka pembeli memiliki kemampuan untuk mengubah alternatif pemasok (European Commission 2003).

Kekuatan pembeli adalah kemampuan pembeli untuk mengurangi harga penjualan pemasok, sehingga menguntungkan pembeli dan nilainya dibawah harga penjualan normal pemasok atau kemampuan pembeli untuk memperoleh syarat-syarat perdagangan yang lebih menguntungkan dibandingkan dengan syarat-syarat perdagangan normal. Harga penjualan normal didefinisikan sebagai harga yang memaksimumkan-laba pemasok dalam kondisi tidak ada kekuatan pembeli. Dalam kondisi persaingan sempurna antara pemasok, harga penjualan normal pemasok adalah harga kompetitif dan kekuatan pembeli adalah kekuatan monopsoni. Dipihak lain, dalam kondisi persaingan antara pemasok tidak 
sempurna, harga penjualan normal berada diatas harga kompetitif dan kekuatan pembeli adalah kekuatan pengimbang (Chen 2008).

Pembeli skala usaha besar memiliki kekuatan terbesar pada saat melakukan pembelian barang dalam jumlah besar. Apabila pemasok menjual pada pembeli skala besar, pembeli akan memiliki leverage signifikan untuk memaksa pemasok menurunkan harga jual barang lebih rendah dan persyaratan lain yang menguntungkan pihak pembeli, karena pemasok khawatir kehilangan pembeli utama dan menempatkan pemasok dalam posisi lemah. Pembeli juga memiliki kekuatan untuk mengatur para pemasok. Namun tidak semua pembeli memiliki tingkat kekuatan posisi tawar yang sama dan kepekaan terhadap harga, kualitas atau pelayanan. Keberadaan pembeli yang kuat mengurangi potensi laba di pasar. Dengan melakukan penekanan harga, melakukan negosiasi peningkatan kualitas, memperbanyak pelayanan dan mengatur pesaing pemasok satu sama lain, pembeli dapat meningkatkan persaingan di pasar. Selanjutnya, memungkinkan dapat mengurangi laba industri (Porter 2004, Ehmke et al. 2009).

Pemasok dapat berada dalam kondisi dibawah tekanan untuk menyetujui berbagai biaya dalam syarat-syarat perdagangan, termasuk biaya promosi yang dibebankan ritel modern dan beban tersebut harus dipenuhi secepatnya. Kondisi tersebut dapat dianggap sebagai timbulnya transfer resiko dari ritel modern terhadap pemasok. Kekuatan pembeli berasal dari sejumlah faktor yang meliputi skala usaha, longgarnya persaingan di pasar, posisi ketergantungan pemasok, yang mendorong pembeli bertindak sebagai "penjaga gawang" antara pemasok dan konsumen. Kekuatan pembeli dapat menyerap surplus pemasok melalui diskon dan beban biaya yang dikenakan terhadap pemasok. Kondisi tersebut dapat mempengaruhi daya saing pemasok dan mendistorsi persaingan dalam pasar pemasok, sehingga pemasok akan mengurangi investasi, pengembangan produk baru dan inovasi. Hal tersebut mengakibatkan kualitas produk menjadi lebih rendah dan pilihan konsumen berkurang (Dodd dan Asfaha 2008, Nicholson dan Young 2012). Dalam mengantisipasi terjadinya distorsi terhadap persaingan sehat dibutuhkan kebijakan persaingan. Kebijakan persaingan dapat dilakukan melalui dua cara, yaitu : (1) Melalui regulasi yang bertujuan untuk menjaga kelangsungan mekanisme pasar ; (2) Memberlakukan hukum persaingan untuk mengatur perilaku dan kegiatan dalam persaingan atau bahkan untuk mengganti atau mendukung peraturan yang telah ada sebelumnya (Lubis et al. 2009).

Kebijakan Persaingan Dan Perlindungan Konsumen. Kebijakan persaingan merupakan salah satu bentuk intervensi pemerintah di pasar. Selain itu untuk meningkatkan efisiensi ekonomi yang relatif bebas nilai atau tidak memihak kepada konsumen atau produsen. Kebijakan persaingan juga dapat bertujuan untuk melindungi kepentingan konsumen di pasar atau meningkatkan kesejahteraan konsumen. Hal ini mengingat dalam dunia nyata seringkali dalam bentuk pasar yang tidak sempurna, konsumen merupakan pihak yang dirugikan. Kerugian konsumen tersebut tergambar dalam bentuk surplus konsumen yang berkurang karena diambil oleh produsen. Kebijakan persaingan dapat dilakukan melalui dua cara, yaitu : (1) Melalui regulasi yang bertujuan untuk menjaga kelangsungan mekanisme pasar; (2) Memberlakukan hukum persaingan untuk mengatur perilaku dan kegiatan dalam persaingan atau bahkan untuk mengganti atau mendukung peraturan yang telah ada sebelumnya (Lubis et al. 2009).

Di Indonesia di berlakukan kebijakan persaingan UU/5/1999 dan perlindungan konsumen UU/8/1999. Kesejahteraan masyarakat dan atau konsumen sebagai tujuan utama kebijakan persaingan. Perlindungan konsumen dan persaingan merupakan dua hal yang 
saling berhubungan dan saling mendukung. Harga murah, kualitas tinggi dan pelayanan yang baik merupakan tiga hal yang mendasar bagi konsumen dan persaingan merupakan cara yang terbaik untuk menjaminnya. Oleh karena itu, hukum persaingan tentu harus sejalan atau mendukung hukum perlindungan konsumen. Berdasarkan substansi UU/5/1999 tentang larangan praktek monopoli dan persaingan usaha tidak sehat, potensi terbentuknya persaingan tidak sehat para pelaku usaha di Indonesia diperlihatkan pada Tabel 1 di bawah ini.

Tabel 1. Potensi Terjadinya Persaingan Tidak Sehat

\begin{tabular}{lll}
\hline $\begin{array}{l}\text { Perjanjian Antar } \\
\text { Pelaku Usaha }\end{array}$ & $\begin{array}{l}\text { Kegiatan } \\
\text { Yang Dilarang }\end{array}$ & Posisi Dominan \\
\hline Oligopoli & Monopoli & Posisi Dominan \\
\hline Penetapan Harga & Monopsoni & Jabatan Rangkap \\
\hline Resale Price Maintenance & Diskriminasi & Pemilikan Saham \\
\hline Pembagian Wilayah & Jual Rugi & $\begin{array}{l}\text { Penggabungan, } \\
\text { Peleburan } \\
\text { dan Pengambilalihan }\end{array}$ \\
\hline Pemboikotan & Persekongkolan & \\
\hline Kartel & & \\
\hline Trust & & \\
\hline Oligopsoni & \\
\hline Integrasi Vertikal & & \\
\hline Perjanjian Tertutup & \\
\hline Perjanjian dengan Pihak Luar & \\
\hline Sumber: UU/5/1999 & \\
\hline
\end{tabular}

Sumber: UU/5/1999

Hubungan Pembeli-Penjual. Hubungan pemasaran (relationship marketing) adalah konsep yang meliputi interaksi antara pembeli dan penjual pada suatu titik dimana beberapa hubungan atau kemitraan dikembangkan untuk memberikan ruang transaksi kedepan. Tujuan hubungan pemasaran adalah untuk mengembangkan dan melayani konsumen melalui kemitraan atau hubungan pemasok dengan pembeli. Hubungan pembeli-penjual (buyer-seller relationships) adalah hubungan atau kemitraan yang harus memiliki manfaat bagi kedua pihak. Hubungan tersebut berkembang melalui pertukaran kemanfaatan bersama. Agar hubungan berlangsung, kerukunan diperlukan, saling berinteraksi, periode pertukaran berkelanjutan diperlukan. Hubungan adalah beberapa interaksi yang terjadi dalam kisaran waktu tertentu. Hubungan antara dua kesatuan (kesatuan, dapat berupa organisasi, orang, masyarakat atau bahkan negara), setiap kesatuan memiliki peran dan norma perilaku yang diharapkan (Fournier 1998, Bhattacharya dan Bolton 2000, De Wulf et al. 2001, Ross dan Robertson 2007 dalam Walz 2009).

Definisi utama hubungan pembeli-penjual adalah sekurang-kurangnya terjadi satu kali interaksi ekonomi, interaksi selanjutnya diharapkan terjadi sesuai dengan berjalannya waktu. Interaksi adalah antar hubungan. Para pihak harus mengetahui indentitas satu sama lain, para pihak harus meyakini bahwa hubungan itu ada, kesaling-tergantungan. Definisi lain hubungan adalah para pihak harus berbagi informasi, harus percaya satu sama lain, 
harus yakin hubungan itu ada, sekurang-kurangnya ada satu kali interaksi ekonomi, para pihak harus mengetahui indentitas satu sama lain (Walz 2009).

Beberapa faktor utama yang menentukan hubungan pemasok-ritel modern menjadi terintegrasi adalah commitment, conflict, conflict resolution, cooperation, trust (Maloni dan Benton 1999). Bisnis membutuhkan mitra perusahaan lain yang memungkinkan untuk berbagi biaya, berbagi resiko, meningkatkan kompetensi inti dan kecepatan untuk sampai ke pasar (Reagan 2002). Derajat minimal kerjasama yang dibutuhkan untuk suatu hubungan dan kerjasama yang lebih erat mencerminkan tingkat kepercayaan dan saling membantu. Kesaling-tergantungan dipengaruhi oleh kelembagaan persaingan, struktur pasar dan perilaku yang menentukan tersedianya pilihan dan sumberdaya kekuatan posisi tawar mitra prospektif di pasar (Scott. 2004). Hubungan pemasok-pembeli adalah dua atau lebih perusahaan melakukan kerjasama dan terlibat dalam berbagi informasi, penyelarasan keputusan dan pelurusan insentif yang bertujuan meraih kinerja super (Simatupang dan Sridharan 2005).

Hubungan pemasok-ritel modern dalam rantai pasokan dipengaruhi lima kekuatan eksternal, yaitu perilaku konsumen, perilaku pesaing, lingkungan sosial ekonomi, lingkungan teknologi, lingkungan kebijakan regulasi dan faktor-faktor internal yang mempengaruhi dan menentukan hubungan pemasok dengan ritel modern. Pemasok dan ritel modern melakukan perubahan aktivitas operasi dan pemasaran yang didukung teknologi informasi, sehingga kesaling-tergantungannya cenderung mengalami perubahan (Dunne dan Lusch 2005). Dalam sebuah jaringan kerja rantai pasokan harus dibuat berdasarkan perhitungan serta memperhatikan dampak terhadap biaya persediaan, fasilitas dan proses. Diperlukan sebuah sistem informasi terpadu yang bertugas dalam pengumpulan, pengolahan, penyimpanan, dan penyebarluasan informasi kepada setiap pemangku kepentingan (Daryanto 2007). Komitmen hubungan dan pengelolaan rantai pasokan sangat penting dalam meningkatkan kinerjanya (Baofeng 2007).

Ritel modern harus melakukan kemitraan lebih erat dengan pemasok dan harus membangun infrastruktur sebelum menerapkan konsep manajemen dan mendorong vertikalisasi serta integrasi rantai pasokan (Hanf 2008). Perusahaan memperbaiki kelemahannya mempergunakan manajemen hubungan kemitraan untuk memaksimumkan kinerja rantai pasokannya. Terbukti dari hasil penelitian bahwa dengan berbagi sumberdaya informasi dan penggunaan e-process, perusahaan dapat meningkatkan keeratan hubungannya dengan mitra untuk meningkatkan daya saing dan dapat memaksimumkan kinerja rantai pasokannya (Chou et al. 2011).

Dalam kaitan bisnis, kekuatan (power) dapat didefinisikan sebagai kemampuan suatu perusahaan (source) untuk mempengaruhi tujuan dan kegiatan perusahaan lain (target) (Maloni dan Benton 1999). Asimetri kekuatan atau ketidakseimbangan kekuatan adalah perbedaan dalam kekuatan antara satu pihak dengan pihak lainnya. Hubungan asimetri kekuatan adalah hubungan dimana satu pihak memiliki kekuatan lebih besar daripada pihak lainnya dan terjadi ketidak-seimbangan serta berpotensi terjadinya konflik dan menghambat hubungan kerjasama usaha satu pihak dengan pihak lainnya (Casciaro dan Piskorski 2005 dalam Schepers 2007). Terdapat hambatan dalam hubungan atau kemitraan, dimungkinkan karena satu pihak berupaya keras merealisasikannya. Namun pihak lain kemungkinan menghentikan kepercayaan (Dwyer, Schurr dan Oh 1987 dalam Mitrega 2009).

Persekutuan strategis ritel modern dengan pemasok dapat mengantisipasi perubahan yang menghambat. Pentingnya membedakan persekutuan strategis dan operasional dalam 
menentukan kepercayaan dan komitmen dalam kolaborasi serta pengaruhnya terhadap kinerja rantai pasokan. Membangun kepercayaan dan komitmen dalam pekerjaan yang bermanfäat agar dapat membentuk persekutuan strategis rantai pasokan dan bermanfaat bagi mitranya (So dan Koo 2009). Konflik pada umumnya menghambat hubungan pembeli dengan penjual, diantaranya yaitu berkaitan dengan lambatnya pembayaran, rendahnya kualitas produk atau jasa, persoalan komunikasi dan masalah yang berkaitan dengan ketidak-handalan hubungan atau kemitraan (Mitrega 2009).

Kerangka Pemikiran Konseptual Penelitian. Berdasarkan pendekatan pembahasan teori-teori dan konsep-konsep serta penelitian-penelitian terdahulu tersebut, apabila digabungkan diharapkan menunjang dan memberikan kajian komprehensif terhadap model kombinasi pengaruh persaingan dan kekuatan pembeli terhadap hubungan pemasok-ritel modern.

Hipotesis Penelitian: Hipotesis yang diajukan adalah, sebagai berikut: $\mathrm{H}_{1}$ : Persaingan berpengaruh terhadap hubungan pemasok-ritel modern; $\mathrm{H}_{2}$ : Kekuatan pembeli berpengaruh terhadap hubungan pemasok-ritel modern. Pada Gambar 2 di bawah ini diperlihatkan kerangka pemikiran konseptual penelitian.

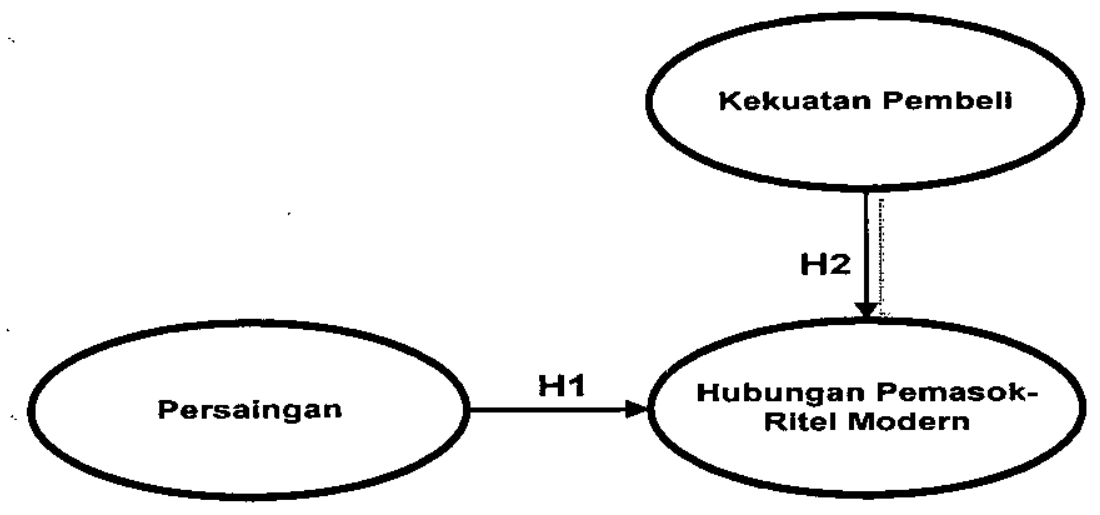

Gambar 2. Kerangka Pemikiran Konseptual Penelitian

Sumber: diolah penulis

\section{METODE}

Metodologi penelitian ini adalah penelitian kuantitatif bersifat deskriptif dan verifikatif. Populasi atau unit analisis adalah perusahaan pemasok kelompok bahan makanan yang beralamat dan beroperasi sebagian besar di Jakarta dan sekitarnya. Perusahaan pemasok tersebut berskala besar, menengah, kecil dan mikro (UU 20/2008 UMKM). 217 perusahaan pemasok dipilih dengan sampling strata non-proporsional. Sebagai bagian dari penelitian kuantitatif, 217 kuesioner (Malhotra 2004) dikirimkan kepada masing-masing kelompok skala perusahaan pemasok dan kemudian 101 kuesioner dapat dikumpulkan, mpat kuesioner tidak lengkap, sehingga diperoleh 97 kuesioner yang ditanggapi secara alid oleh pemasok makanan kemasan, yang terdiri dari 48 perusahaan pemasok skala li aha besar, 18 skala menengah, 10 skala kecil dan 23 skala mikro. Kuesioner yang dibuat

1. rtindak sebagai instrumen pengukuran yang sesuai dengan kerangka konseptual dan 
ketentuan praktis. Seluruh data primer dikumpulkan dari jawaban pertanyaan yang terstruktur pada kuesioner. Kuesioner menggunakan five-point likert scale dan hybrid ordinally-interval scale (Hermawan 2009). Penelitian ini menggunakan cakupan waktu bersifat one shot dengan tipe cross-sectional, yang surveinya dilakukan pada bulan Mei Juli 2013. Penelitian ini bersifat verifikatif, yaitu untuk mengetahui hubungan antar variabel melalui pengujian hipotesis dan pemodelan serta teknik solusi menggunakan metode Partial Least Square-PLS (Chin 2000, Yamin dan Kurniawan 2011, Ghozali 2011, Mateos 2011).

\section{HASIL DAN PEMBAHASAN}

Pada Tabel 2 di bawah ini diperlihatkan karakteristik perusahaan pemasok yang meliputi, yaitu: (1) Perbandingan jumlah dan persentase responden yang menduduki jabatan pada perusahaan pemasok; (2) Jumlah dan presentase hasil produksi dan perdagangan; (3) Skala usaha perusahaan pemasok yang bertindak sebagai responden dalam penelitian ini.

Tabel 2. Karakteristik Perusahaan Pemasok

\begin{tabular}{lcc}
\hline & Jumlah & Persentase (\%) \\
\hline Jabatan: & 8 & 8.25 \\
- Direksi & 59 & 60.82 \\
- Manajer & 30 & 30.93 \\
- Staf & & \\
Hasil Produksi Dan Perdagangan & 47 & 48.45 \\
- Makanan Kemasan & 29 & 29.90 \\
- Minuman Kemasan & 18 & 18.56 \\
- Perawatan Diri & 2 & 2.06 \\
- Makanan dan Minuman Kemasan & 1 & 1.03 \\
- Makanan, Minuman Kemasan dan Perawatan Diri & & \\
Skala Usaha: & 46 & 47.42 \\
- Besar (> Rp 10 Milyar) & 18 & 18.56 \\
- Menengah (Rp 500 Juta - Rp 10 Milyar) & 10 & 10.31 \\
- Kecil (Rp 50 Juta - Rp 500 Juta) & 23 & 23.71 \\
- Mikro (<Rp 50 Juta) &
\end{tabular}

Sumber: data diolah menggunakan SPSS 18

Hasil Evaluasi Model Pengukuran. Dari hasil pengolahan seluruh konstruk penelitian didapatkan nilai factor loading dan nilai cronbach alpha untuk pengujian validitas dan reliabilitas uji coba instrumen dalam kuesioner dengan menggunakan SPSS 18. Pengujian sampel sebanyak 30 responden pemasok memberikan nilai factor loading dari seluruh indikator yang membentuk dimensi, faktor atau konstruk sudah memiliki nilai lebih besar (0.553-0.960) dari 0.55 (Hair et al. 2006). Oleh karena itu disimpulkan seluruh indikator tersebut dikatakan valid, dimana terdapat konsistensi internal dalam pernyataanpernyataan tersebut sehingga dapat membentuk konstruk dari seluruh dimensinya. Demikian juga dengan koefisien cronbach's alpha seluruh dimensi atau konstruk dengan sejumlah item pertanyaan, seluruhnya lebih besar $(0.797-0.960)$ dari 0,60 yang berarti seluruh konstruk reliabel. Pada Gambar 3 di bawah ini diperlihatkan konstruk persaingan antar ritel modern (RT), persaingan antar pemasok (PS), beban biaya (BB), penentuan harga (HR), sanksi (SS) adalah konstruk first order. Konstruk persaingan dan kekuatan 
pembeli adalah konstruk second order, hubungan pemasok dengan ritel modern (PS-RT) adalah konstruk third order. Variabel laten dalam penelitian ini merupakan konstruk multidimensi. Masing-masing konstruk yaitu, konstruk first order masing-masing diukur dengan indikator RT2 sampai dengan SS1 yang bersesuaian. Pada Gambar 3 di bawah ini juga diperlihatkan hubungan keseluruhan variabel laten atau konstruk dan besaran koefisien jalurnya.

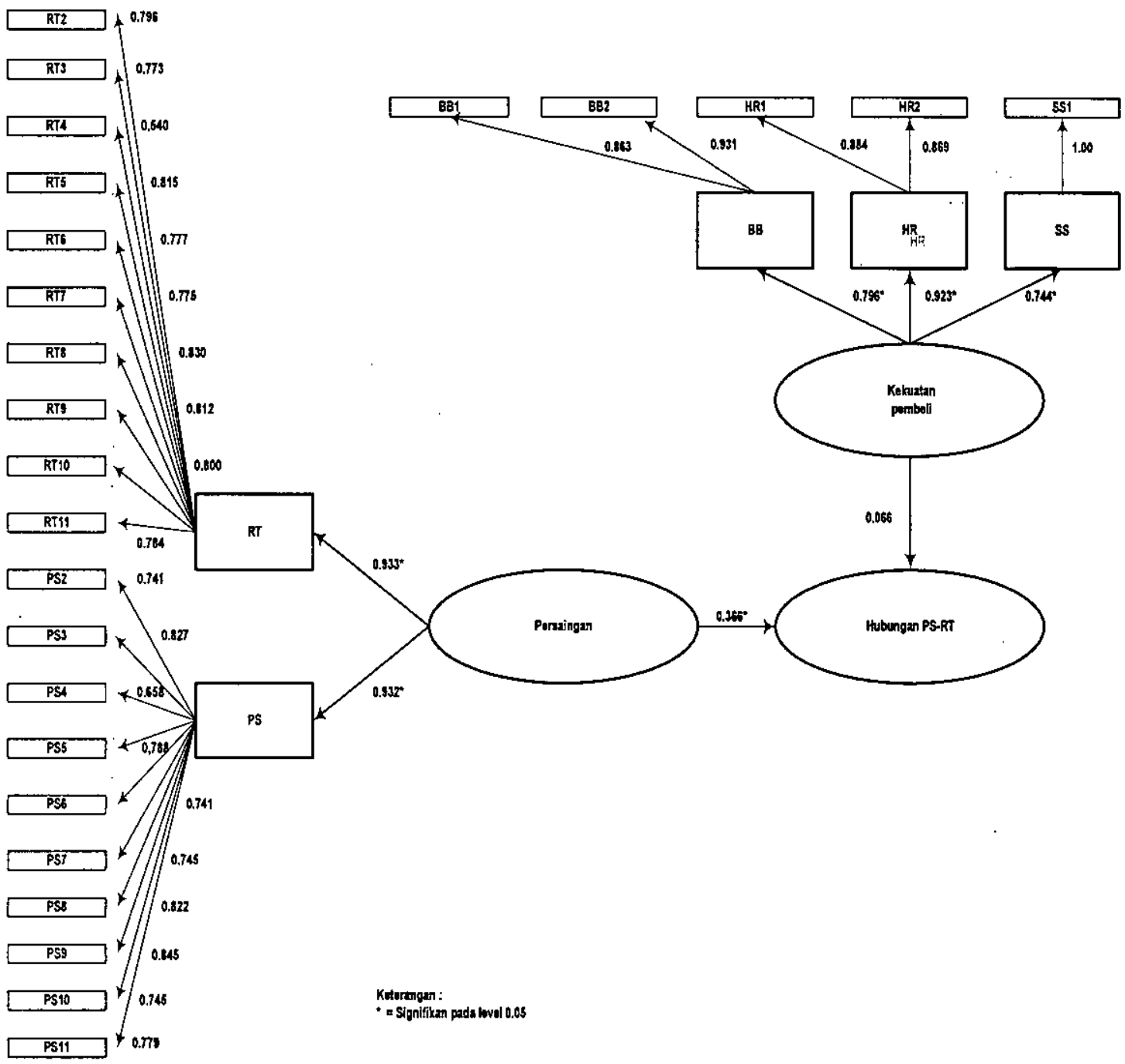

Gambar 3. Hubungan Struktural Konstruk, Dimensi Dan Indikator Penelitian Sumber: data diolah

Evaluasi Model Pengukuran. Pernyataan-pernyataan pilihan jawaban pemasok terhadap pertanyaan-pertanyaan kuesioner dari 97 responden termasuk 30 responden sebelumnya dievaluasi kembali dengan metode PLS. Uji validitas diskriminan tahap pertama melalui nilai cross loading dihasilkan indikator-indikator yang memiliki validitas diskriminan yang baik. Uji tahap kedua menilai validitas diskriminan dari konstruk dengan melihat 
nilai AVE. Berdasarkan nilai akar AVE seluruh konstruk memiliki validitas diskriminan yang baik. Hasil output latent variable correlation digunakan untuk membandingkan nilai maksimal korelasi konstruk dengan nilai akar AVE. Hasilnya didominasi oleh konstruk yang memiliki nilai akar AVE yang lebih tinggi dari nilai maksimal korelasi. Dengan demikian, seluruh konstruk dimensi memiliki validitas diskriminan yang baik. Pada Tabel 3 di bawah ini diperlihatkan nilai AVE dan akar AVE konstruk penelitian,

Tabel 3. Nilai AVE Dan Akar AVE Konstruk Penelitian

\begin{tabular}{cccc}
\hline & & & Reliabilitas \\
\hline Konstruk & AVE & Akar AVE & Akar AVE > AVE \\
Regulasi & 0.278109 & 0.52736041 & Baik \\
RT & 0.599505 & 0.77427708 & Baik \\
PS & 0.594549 & 0.77107004 & Baik \\
Persaingan & 0.517544 & 0.71940531 & Baik \\
BB & 0.805688 & 0.89760125 & Baik \\
HR & 0.768502 & 0.87664246 & Baik \\
SS & 1 & 1 & Baik \\
Kekuatan Pembeli & 0.573441 & 0.75725887 & Baik \\
Hubungan PS-RT & 0.221517 & 0.47065593 & Baik \\
\hline
\end{tabular}

Sumber: Diolah menggunakan SmartPLS

Evaluasi yang berkaitan dengan reliabilitas konsistensi internal dapat diperiksa pada nilai reliabilitas komposit dan cronbach's alpha. Hasil output reliabilitas komposit dan cronbach's alpha menunjukkan bahwa nilai reliabilitas komposit untuk semua konstruk adalah nilainya diatas 0.7 , yang menunjukkan bahwa semua konstruk pada model diestimasi memenuhi kriteria validitas diskriminan. Pada cronbach's alpha nilai yang disarankan adalah diatas 0.6 dan hasilnya menunjukkan bahwa nilai cronbach's alpha untuk semua konstruk berada diatas 0.6 (Chin 2000, Ghozali 2011). Nilai terendah pada penelitian sebesar 0.698987 (HR). Dengan demikian dapat disimpulkan bahwa seluruh konstruk yang diuji memiliki reliabilitas yang baik. Pada Tabel 4 di bawah ini diperlihatkan nilai reliabilitas komposit dan cronbach's alpha konstruk penelitian,

Tabel 4. Nilai Reliabilitas Komposit Dan Cronbach's Alpha Konstruk Penelitian

\begin{tabular}{cccc}
\hline & Reliabilitas & Cronbach's & Reliabilitas \\
\hline Konstruk & Komposit $>0.7$ & Alpha $>0.7$ & Konstruk \\
RT & 0.936765 & 0.924643 & Baik \\
PS & 0.935881 & 0.923525 & Baik \\
Persaingan & 0.95474 & 0.949332 & Baik \\
BB & 0.892251 & 0.764579 & Baik \\
HR & 0.869091 & 0.698987 & Baik \\
SS & 1 & 1 & Baik \\
Kekuatan Pembeli & 0.868975 & 0.809915 & Baik \\
Hubungan PS-RT & 0.959759 & 0.957184 & Baik \\
\hline
\end{tabular}

Sumber: Diolah menggunakan SmartPLS 
Hasil Evaluasi Model Struktural. Berdasarkan evaluasi terhadap model struktural dapat diperoleh nilai-nilai koefisien jalur (Lihat Gambar 3), berikut t-statistik keseluruhan konstruk, sehingga dapat diketahui bagaimana hubungan antar variabel dan pengaruh variabel terhadap variabel lainnya (signifikansi), kekuatan hubungan antar variabel, pengaruh variabel independen tertentu terhadap variabel dependen untuk menguji hipotesis penelitian yang diajukan.

Pengaruh Dimensi Regulasi, Persaingan dan Kekuatan Pembeli. Hasil uji model struktural menunjukkan perolehan hasil konstruk second order persaingan berpengaruh sangat kuat terhadap dimensi konstruk first order RT dan PS, searah dan signifikan. Konstruk persaingan antar ritel-RT $\left(\lambda_{\mathrm{RT}}=0.933, \mathrm{t}=50.786, \mathrm{p}<0.05\right)$; Persaingan antar pemasok-PS $\left(\lambda_{\mathrm{RT}}=0.932, \mathrm{t}=56.030, \mathrm{p}<0.05\right)$. Hasil uji model struktural menunjukkan perolehan hasil konstruk second order kekuatan pembeli berpengaruh sangat kuat terhadap dimensi konstruk first order BB, HR dan SS, searah dan signifikan. Persyaratan beban biaya tambahan-BB $\left(\lambda_{\mathrm{BB}}=0.796, \mathrm{t}=14.282, \mathrm{p}<0.05\right)$, penentuan harga dan pembayaran-HR $\left(\lambda_{\mathrm{HR}}=0.923, \mathfrak{t}=57.836, \mathrm{p}<0.05\right)$, perjanjian dan sanksi-SS $\left(\lambda_{\mathrm{SS}}=0.744\right.$, $\mathrm{t}=13.862, \mathrm{p}<0.05)$.

Pengaruh Persaingan Terhadap Hubungan PS-RT. Hasil uji model struktural mengkonfirmasikan bahwa konstruk second order persaingan $\left(\gamma_{2}=0.366, t=5.246\right.$, $\mathrm{p}<0.05$ ) berpengaruh terhadap konstruk third order hubungan PS-RT. Koefisien jalur tersebut bernilai cukup besar, korelasi positif dan cukup kuat. Hasil uji hipotesis dalam evaluasi model struktural tersebut diatas mengkonfirmasikan jawaban terhadap pertanyaan tujuan penelitian bahwa pengaruh persaingan terhadap hubungan PS-RT adalah pengaruh yang cukup kuat, searah dan signifikan.

Pengaruh Kekuatan Pembeli Terhadap Hubungan PS-RT. Hasil uji model struktural mengkonfirmasikan bahwa konstruk second order kekuatan pembeli $\left(\gamma_{3}=0.066, t=2.005\right.$, $\mathrm{p}<0.05$ ) berpengaruh terhadap konstruk third order hubungan PS-RT. Koefisien jalur tersebut bernilai kecil, korelasi positif dan lemah. Hasil uji hipotesis dalam evaluasi model struktural tersebut diatas mengkonfirmasikan jawaban terhadap pertanyaan tujuan penelitian bahwa pengaruh kekuatan pembeli terhadap hubungan PS-RT adalah pengaruh yang lemah, searah dan signifikan.

Evaluasi Goodness of Fit. Evaluasi kesesuaian model (goodness of fit) dengan metode PLS menggunakan interpretasi $R$-square. Berdasarkan hasil analisis, secara bersama-sama konstruk persaingan, kekuatan pembeli dan konstruk lainnya mampu menjelaskan variabilitas konstruk hubungan PS-RT sebesar 98.92\%, sedangkan $1.08 \%$ dijelaskan oleh variabel lain yang tidak diteliti dalam model ini. Chin (1998) dalam Yamin dan Kurniawan (2011) menjelaskan bahwa kriteria nilai $R$-square dalam tiga klasifikasi, yaitu batas nilai 0.67 (substansial), batas nilai 0.33 (moderat) dan batas nilai 0.19 (lemah).

\section{PENUTUP}

Kesimpulan. Persaingan berpengaruh cukup kuat terhadap hubungan pemasok-ritel modern. Namun pengaruh persaingan belum optimal. Perilaku persaingan ritel modern, secara ekspansif mengembangkan jaringan gerai dan cenderung memenuhi ekspektasi konsumen, peningkatan konsentrasi dan kekuatan posisi tawar ritel modern, sedangkan 
pemasok hanya terfokus memperebutkan akses pasar, sehingga kekuatan posisi tawar pemasok sangat lemah dalam hubungannya dengan kekuatan posisi tawar ritel modern.

Kekuatan pembeli berpengaruh lemah terhadap hubungan pemasok-ritel modern. Lemahnya pengaruh kekuatan pembeli ditandai dengan terjadinya pembebanan biaya berlebihan terhadap pemasok, ședangkan kekuatan pembeli yang ditandai dengan penentuan harga dan sanksi tidak terjadi.

Saran. Penelitian selanjutnya disarankan melakukan analisis pengaruh perilaku kekuatan pembeli terhadap pemasok skala kecil dan menengah domestik. Selain itu penelitian mengenai variasi hubungan pemasok dengan ritel modern. Penelitian lain juga adalah eksplorasi terhadap faktor penghambat persaingan dan pengendalian kekuatan pembeli, persaingan pada praktek dua-sisi pasar, persaingan merek produk pemasok dan label sendiri ritel modern.

Persaingan antar ritel modern tidak berpengaruh optimal terhadap hubungan pemasokritel modern, perlu penanganan tegas melalui kebijakan persaingan terhadap kekuatan pembeli dan meningkatkan kesejahteraan konsumen.

Kekuatan pembeli yang diindikasikan melalui beban biaya berlebihan oleh ritel modern terhadap pemasok perlu dicermati dalam hubungan pemasok-ritel modern dan kaitannya dengan kebijakan persaingan UU/5/1999.

\section{DAFTAR RUJUKAN}

Akpinar M. (2007). Institutional Impacts on Industry Structure: The Block Exemption Regulation. Management Research News, 30 (3): pp.173-186.

Arifin B. (2010). Lingkungan Ekonomi dan Bisnis: Kebijakan Publik dan Proses Politik. Bogor: MB-IPB.

Armstrong M, Wright J., (2005). Two-sided Markets, Competitive Bottlenecks and Exclusive Contracts, University College London and National University of Singapore. http://profile.nus.edu.sg/fass/ecsjkdw/website\%20version.pdf

Baofeng, H., (2007). An Exploratory Study of Power, Relationships Commitment, Supply Chain Integration and Performance, Decision Science and Managerial Economics. Ph.D Thesis, The Chinese University of Hongkong.

Baye, M:R., (2009). Managerial Economics and Business Strategy, Sixth Ed., McGrawHill International Edition, pp. 238-239, 255-257.

Berasategi J., (2013). Supermarket Power : Serving Consumers Or Harming Competition, EU Current Status: DG Comp. https://www.slf.dep.no/no/om-slf/serviceoginnsyn/presentasjoner/_attachment/21295

Berasatagi J., (2010). Hub \& spoke is dead : welcome to the era of retailer power, BIICL Hub \& Spoke Conference, London. www.biicl.org/files/5150_holding_slide_1511_hub.ppt.

Charoensiriwath C., (2004). Competition in Supply Chain with Service Contributions. Georgia: Ph.D Thesis in Industrial and Systems Engineering, Georgia Institute of Technology.

Chen Z., (2008). Defining Buyer Power, Professor of Economics with Carleton University, and Senior Consultan with Delta Economics Group. 
Chin WW., (2000). Partial Least Square for researchers: a overviewand presentation of recent advances using the PLS approach, http://discnt.cba.uh.edu/chin/indx.html, 2000.

Chin WW., (2001). PLS Graph 3.0 version, Bootstrapping and Jacknifing, student version www. bauer.uh.edu

Chou HP, Shih YY, Wang JH. (2011). Supply chain performance improvement through partner relationship management in the high tech industry. UK International Journal of Management Science and Engineering Management. 6:210-218, 201.

Chowdhury SK, Gulati A, Gumbira-Sa'id E. (2007). The Rise of Supermarkets and Vertical Relationships in the Indonesian Food Value Chain. Causes and Consequences. Asian Journal of Agriculture and Development. 2:1\&2: pp 39-48

Chuah P, Wong WP, Ramayah T, Jantan M ., (2010). Effect of Power Asymmetry and Competition Intensity: The Role of High Involvement and Economics Practices in Supplier Performance, Journal of Enterprise Information Management, 23(6) : pp 724758

Cooper DR, Schindler PS. (2008). Business Research Methods, Tenth Edition. McGrawHill International Edition.

Daryanto A., (2007). Peningkatan Nilai Tambah Industri Perunggasan Melalui Supply Chain Management: Bogor, MB-IPB.

Dobson PW, Clarke R, Davies S, Waterson M., (2001). Buyer Power and its Impact on Competition in the Food Retail Distribution Sector of the European Union. Journal of Industry, Competition and Trade, 1:3, 247-281.

Dodd L, Asfaha S., (2008). Rebalancing The Supply Chain : Buyer Power, Commodities and Competition Policy, Traidcraft, South Centre.

Dunne PM, Lusch RF., (2005). Retailing, International Student Edition, Thomson, SouthWestern.

Ehmke C, Fulton J, Akridge J, Erickson K, Communications E, Linton S., (2009). Industry Analysis : The Five Forces, Purdue University. AICC.

Einav L, Levin J., (2012). Empirical Industrial Organization: A Progress Report. Journal of Economic Perspectives 24(2):145-162.

Essig M, Amann M., (2009). Supplier satisfaction: Conceptual basics and explorative findings. Journal of Purchasing \& Supply Management 15:103-113.

Fearne A, Duffy R, Hornibrook S., (2005). Justice in UK supermarket buyer-supplier relationships. An empirical analysis. International Journal of Retail \& Distribution Management $33(8): 570-582$.

Ghozali I., (2011). Structural Equation Modelling, Metode Alternatif dengan Partial Least Square (PLS). Edisi 3, Semarang: Badan Penerbit Universitas Dipenogoro.

Hair JF, Rolph EA, Ronald LT, William CB. (2006). Multivariate Data Analysis, $6^{\text {th }}$ Edition, New Jersey, Pearson Prentice-Hall Int.

Heatwole KB. (2006). A Determination of the Association of Competition and Regulation With Hospital Strategic Orientation (Dissertation). Virginia: Virginia Commonwealth University.

Hermawan A., (2009). Penelitian Bisnis, Paradigma Kuantitatif, Grasindo, Penerbit PT. Gramedia Widiasarana Indonesia, Jakarta.

Hill JD, Llandro P., (2012). The Effect of Competition on Supply Chain Decision Making. Proceedings of the 2012 Industrial and Systems Engineering Research Conference G. Lim and J.W. Herrmann, eds. 